\title{
The Effect of Pedagogic Competence, Giving Compensation on Teacher Work Motivation (Study at Vocational High School Manado City, Indonesia)
}

\author{
Altje Salele Henny N Tambingon Shelty D.M Sumual \\ Magister Education Management Postgraduate Program \\ Manado State University, Indonesia
}

\begin{abstract}
The purpose of this study is to obtain the results of an analysis of the effect of pedagogic competence and compensation for work motivation of vocational teachers in the city of Manado. More specifically the purpose of this study is to obtain the results of the analysis: The effect of pedagogic competence on the work motivation of state vocational school teachers in the city of Manado, The effect of giving compensation to the work motivation of teachers at the State Vocational School in Manado city, The effect of pedagogic competence, compensation, on the work motivation of teachers of State Vocational Schools in the City of Manado. Object that becomes the variable in this study is Pedagogic competence, Giving compensation and working motivation of teachers at Manado State Vocational School. While the subjects of the analysis are teachers at the Manado City Public Vocational School. The research location is State Vocational Schools in Manado City. This research was conducted from October 2018 to April 2019. The population in this study is the overall characteristics of the study regarding pedagogic competence of teachers, the provision of teacher compensation and teacher work motivation with the population unit are all teachers at the Manado City Public Vocational School with a total of 504 people spread across 9 (nine) Public Vocational Schools in Manado City and recorded in the data teachers of Manado City State Vocational School Academic Year 2018/2019Determination of the sample in this study will use an error rate of $10 \%$, with a confidence level of $95 \%$ using the formula from Taro Yamane. Using this formula, a sample of 84 teachers was obtained. Based on the results of the test, it can be seen that the questionnaire reliability coefficient pedagogic competence variable $(\mathrm{X} 1) \mathrm{r} 1=0.971$, teacher compensation $\mathrm{r} 1=0.969$, and the Aplha-Cronbach reliability coefficient $(r=0.981)$. The data analysis technique in this study uses simple correlation analysis and multiple regression analysis with the help of SPSS 21 . The stages of the analysis include (1) descriptive analysis, (2) test requirements analysis, (3) hypothesis testing. Based onthe study, conclusions can be drawn as follows: 1. In general, the level of feasibility of pedagogical skills of state vocational school teachers in the city of Manado is quite high. This means that teachers in general have fully understood the duties, work and obligations of the teacher so that they can carry out professionally.2. In general, the provision of compensation that is perceived by state vocational school teachers in the city of Manado is already quite high. This means that compensation has been carried out fairly. The level of teacher perceptions of the provision of compensation for State Vocational Schools in the city of Manado is quite feasible.3. In general the work motivation of the State Vocational School teachers in the city of Manado is quite high. This means that the work motivation of teachers at Manado City Vocational School is quite good.4. The pedagogical ability of the teacher has a significant contribution to the motivation of work of the State Vocational School teachers in the city of Manado. This means that the higher the pedagogical ability of the teacher will also contribute high to the motivation of the teacher's work. This means that the work motivation of the teacher depends on pedagogic abilities.5. The provision of compensation has a significant contribution to the motivation of work of the State Vocational School teachers in the city of Manado. This means that the provision of compensation contributes significantly to the work motivation of the teacher.6. Teacher's pedagogical ability and the provision of compensation together have a significant contribution to the work motivation of teachers of Vocational Schools in the city of Manado. This means that the teacher's pedagogic ability and compensation, together provide meaningful contributions to the motivation of teacher work
\end{abstract}

Keywords: Pedagogic Competence, Giving Compensation On Teacher Work Motivation

DOI: $10.7176 / \mathrm{JEP} / 10-21-01$

Publication date:July $31^{\text {st }} 2019$

\section{Introduction}

Education has a very strategic role in the progress of a nation. Through educational efforts can produce quality human resources, who can utilize their potential and other resources to achieve prosperity, both for themselves, their families, the community and the nation. School is one of the educational organizations that can be said as a forum to achieve national development goals. The success of education goals in schools depends on the human resources available in the school, namely the principal, teachers, students, administrative staff, and other education personnel. To form human beings that are in accordance with national development goals, which are essentially aimed at improving human quality, qualified educators are needed. The teacher is the spearhead of implementing 
education in the field, so the existence of teachers is crucial in the implementation of education. The existence of teachers is the main actor as a facilitator of the organizers of student learning processes. Therefore the presence and professionalism are very influential in realizing the national education program.

Republic of Indonesia Law No. 20 of 2003, concerning the National Education System Chapter XI article 39 states that:(1) Education personnel are tasked with carrying out administration, management, developers, supervisors and technical services to support the education process in the education unit.(2) Educators are professionals who are tasked with planning and implementing the learning process, assessing learning outcomes, conducting guidance and training, and conducting research and community service, especially for educators in universities. The teacher as a human being, has character, personality and needs that are different from one another. These factors influence and result in teacher work motivation varying from one another.

The teacher has an important role, is a strategic position, and is responsible for national education. The teacher has the task as an educator, teacher and trainer. Educating means continuing and developing life values. While teaching means continuing and developing knowledge, knowledge and technology. Training means developing skills in students (Usman, 2002: 7). In addition to the above tasks the teacher is also a motivator for students to learn lessons, so that if the teacher's work motivation is not optimal it will have an impact on the quality of graduates.

Based on observations, the work motivation of vocational high school (SMK) teachers in the city of Manado in carrying out basic tasks has not been maximized. The indications are that relatively many teachers often arrive late at school and enter classes not in accordance with the time set in the schedule to carry out the main task of teaching. In teaching is inconsistent and irrelevant to teaching preparation (PM), there is no teaching preparation, teachers often leave the classroom, even many teachers seek additional income so that it has an impact on their teaching obligations, and so on. This results in the learning process not optimal.

The still low motivation of teacher work is currently caused by factors that originate from the internal teacher itself and other factors that come from outside. These factors include:(1) Teachers' pedagogic competencies that have not yet been built should every teacher need to show a competent attitude as an educator, not just as a teacher. (2) Lack of teacher interest to add insight as an effort to improve pedagogical competence.(3) The number of students in one class is quite large.(4) Low teacher interest in the world of writing. (Djamal Z, 2005) in Riduwan, (2009: 356). (5) Income earned by the teacher has not been able to meet the daily needs of the family adequately. Therefore, efforts to increase knowledge and information were hampered due to funds to buy books, subscribe to newspapers, the internet was not available. Even to meet kitchen needs, it is not uncommon for a teacher to do other side jobs.

Motivation will arise in the teacher if there is attention, conformity, trust and satisfaction given by the principal, and smooth compensation from the school. One of the characteristics of the success of the school assessed by the community is the achievement achieved by students every year. Schools that are considered good and considered quality if students have high achievements. The quality of education and graduates is often seen as dependent on the teacher's role in managing the teaching components used in the teaching and learning process, which is the responsibility of the school. Manado City has 9 Public Vocational Schools and 27 Private Vocational Schools.

Distribution of Vocational Schools, both State and Private, is available in each sub-district and thus access to affordability of students with vocational high schools is very easy. The State Vocational High School (Vocational School) in Manado City is a barometer of schools in North Sulawesi, so it is always a sample in research or activities related to education at the level of Manado City, North Sulawesi Province, and from the National level, while student learning achievement between Vocational Schools is not the same. There are schools that have high student achievement, there are schools that have student achievement scores that are mediocre and there are also schools where students' learning achievement is lacking. Schools with students who have outstanding achievements and schools with outstanding students are less required to improve the quality of their learning processes and outcomes.

Increasing school performance is determined by various factors, including compensation. The attention of organizations or schools towards rational and fair compensation arrangements is very necessary. If the teacher views the provision of inadequate compensation for work performance, their motivation and job satisfaction tend to decline. According to Ruky (2001: 10), compensation is everything that employees receive as remuneration for their work, and compensation itself can be divided into two, namely direct and indirect compensation. Direct compensation is compensation for services to employees who are received directly, routinely or periodically because they have provided assistance or donations to achieve organizational goals and direct compensation includes salaries, bonuses or incentives, commissions. In addition to direct compensation, indirect compensation also has an equally important role to improve employee performance. Indirect compensation includes holiday allowances and health benefits. Compensation given by the school is of two kinds, namely direct compensation and indirect compensation. Direct compensation in the form of basic salary and incentives, while indirect compensation in the form of allowances consisting of holiday allowances, service benefits, office allowances, and 
other benefits in accordance with applicable regulations.

The implementation of the system in payroll does not have a positive impact on the teacher because the salary provided is relatively small and not based on education, position, and work experience. This has become one of the causes of the decline in teacher motivation. One effort to improve the quality of schools is done by increasing teacher work motivation by taking into account the factors of pedagogic competence, compensation. Based on this description, researchers are interested in conducting further research on: "The Effect of Pedagogic Competence, Compensation for Work Motivation of Vocational Teachers in the City of Manado."

The purpose of this study is to obtain the results of an analysis of the effect of pedagogic competence and compensation for work motivation of vocational teachers in the city of Manado. More specifically the purpose of this study is to obtain the results of the analysis: 1 . The effect of pedagogic competence on the work motivation of state vocational school teachers in the city of Manado2. The effect of giving compensation to the work motivation of teachers at the State Vocational School in Manado city3. The effect of pedagogic competence, compensation, on the work motivation of teachers of State Vocational Schools in the City of Manado.

\section{Literature review}

\subsection{Pedagogic Competence.}

Motivation is the driving force for someone to carry out activities to achieve his goals. There are two factors that influence a person's motivation, namely self-derived factors called intrinsic factors such as beliefs, desires, and needs and factors that come from outside themselves such as obedience, reluctance, or fear of the leader, the existence of rewards and penalties. The importance of motivating members in an organization has made many experts do a lot of research to study and examine various motivational concepts and theories. The following will discuss various theories and concepts proposed by experts.Based on etymology, motivation comes from the Latin word movere which means encouragement or movement. According to G.R Terry in Hasibuan (2008: 95) suggests that motivation is a desire that is contained in an individual person who stimulates him to take actions.

Steven P. Robbins and Timothy A. Judge (2001: 222, Interpreting: H. Pujaatmaka in Benjamin Molan) defines that:Motivation is a process that explains the intensity, direction, and perseverance of an individual to achieve any goal. There are three main elements in motivation, namely intensity, direction, and perseverance. Intensity is related to how actively someone tries. Every effort made must be linked and directed towards organizational goals. While perseverance is a measure of how long a person can maintain his business.According to Ernes J. Mc Cormik in Mangkunegara (2007: 94), that "Motivation to work in relation to the environment as an influential condition arouses, directs, and maintains behaviors related to the work environment". While the understanding of motivation according to David Mc Clelland in Mangkunegara (2007: 166), namely: "Motivation is the willingness to issue a high level of effort for organizational goals conditioned by the ability of that effort, to meet some individual needs".

Motivation is a very important factor in an organization both formal and non-formal organizations because motivation can encourage each individual to work vigorously and actively in accordance with their respective roles, duties and responsibilities in order to achieve the stated organizational goals. In school if every teacher has high motivation, they will work seriously and will always improve their competencies to support their duties and positions.Motivation is an impulse that arises in a person consciously or unconsciously to do something with a specific purpose. (Large Indonesian dictionary, fourth edition, 2008: 950)."Motivation is the desire to do something, while the motive is need (need), desire (wish), encouragement (desire) or impulse. Motivation is a desire found in an individual who stimulates him to take actions or something that is the basis or reason for someone behaving. (Usman, 2006: 223).

Robbins (2003: 208) defines motivation as a process that produces an intensity, direction, and individual perseverance in an effort to achieve a goal. The intended purpose is the purpose of the organization. While Siagian (2004: 138) states that:"Motivation is the driving force that causes a member of the organization to be willing and willing to mobilize capabilities in the form of expertise or skills, energy and time to organize various activities that are their responsibility and fulfill their obligations, in order to achieve predetermined organizational goals and objectives" .In the definition stated by Robbins above, there are three key elements, namely: Intensity, purpose, and perseverance. The explanation according to Robbins (2003: 208) as follows:"Intensity involves how hard someone tries. This is the most focused element in the context of motivation. However, high intensity will not bring the desired results unless the effort is directed to a goal that benefits the organization. Therefore, the quality of the effort and its intensity must be considered. Efforts directed towards, and consistent with the goals of organizations, are efforts that should be pursued. Finally, motivation has a dimension of perseverance. This is a measure of how long a person can maintain his business. Motivated individuals stay on the job long enough to achieve their goals.

Sumarsono (2004: 240) states that work motivation is often used to refer to motivation in the work environment. Management literature is often used to explain motivation that has something to do with work.Quoting Wexley and Yulk (1998: 98), Sumarsono (2004: 240) provides the following limits:"Motivation can 
be interpreted as a process where behavior is driven and directed. The limit can be interpreted that motivation is the giving or arising of motives. Can also be interpreted as a state of being a motive. Understanding motivation is something that gives rise to enthusiasm or work motivation. This limitation causes motivation to work in the psychology of work commonly called a driver of morale ".The definition above can explain clearly why an employee is willing to do a job at an institution (organization). This means that this willingness is certainly due to the encouragement, motive or stimulus in an employee. More concretely, that encouragement or motive is in the form of needs that arise in an employee that must be fulfilled by working.

Motivation theory is understood so that leaders are able to identify what motivates employees to work, the relationship of work behavior with motivation, and why high-achieving employees (Mangkunegara, 2005: 62). Furthermore Mangkunegara (2005: 63) categorizes motivational theories into three groups, namely:

1). Motivational theory with content theory, which emphasizes more on what factors make employees perform certain actions (for example Abraham Maslow's motivational theory).

2). Motivational theory with process theory, which is not only emphasizing what factors make employees act, but also how the employee is motivated (for example the motivation theory of David Mc Clelland).

3). Motivation theory with a reinforcement approach (reinforcement theory), which is more emphasis on factors that can improve an action carried out or that can reduce an action (for example the motivation theory from Skinner).

Some theories about motivation can be described as follows:1). Theories of motivational needs

a). Maslow's Need Hierarchy TheoryNeeds can be defined as a gap or conflict experienced between a reality with an impulse that is in someone. If the employee's needs are not met, the employee will show disappointed behavior. Conversely, if their needs are met, the employee will show happy behavior as a manifestation of his satisfaction.Maslow (in Mangkunegara, 2005: 63) argues that the hierarchy of human needs is as follows:

- Physiological needs, namely the need to eat, drink, physical protection, breathe, sexually. This need is the lowest level of needs or also called the most basic needs.

- Security needs, namely the need for protection from threats, dangers, conflicts, and the environment.

- The need for belonging, that is the need to be accepted by the group, affiliated, interacted, and the need to love and be loved.

- The need for self-esteem, namely the need to be respected and valued by others.

- The need to actualize themselves, namely the need to use abilities, skills, and potential. The need to argue by expressing ideas gives an assessment and criticism of something.

b). Hezberg Two Factor TheoryThe two-factor theory was developed by Herzberg using Maslow's theory as his reference point. Two factors that cause a feeling of satisfaction or dissatisfaction according to Herzberg (in Mangkunegara, 2005: 67) are:"Maintenance factors (maintenance factors) and motivational factors (motivational factors). Maintenance factors are also called dissatisfiers, hygiene factors, job context, extrinsic factors which include administration and company policy, quality of supervision, relations with supervisors, subordinate relations, wages, job security, working conditions, and status. While motivational factors are also called satisfiers, motivators, job content, intrinsic factors which include encouragement of achievement, recognition, advancement, work it self, opportunity to develop, and responsibility.

c). Achievement TheoryMc Clelland, an American psychologist from Harvard University, in his motivational theory suggests that a person's productivity is largely determined by the "mental virus" that is on him. A mental virus is a mental condition that encourages a person to be able to achieve his achievements to the fullest. In Mangkunegara (200: 67), the mental virus in question consists of three impulses of need, namely:- Need of achievement (need for achievement)- Need of affiliation (the need to expand relationships)- Need of power.

\subsection{Pedagogic Competence}

Teacher competency is a set of knowledge, skills, and behaviors that must be possessed, internalized, mastered, and actualized by the teacher in carrying out professional duties. Based on Government Regulation (PP) Number 18 of 2007 concerning Teachers, it is stated that the competencies that must be possessed by Teachers include pedagogical competencies, personality competencies, social competencies, and professional competencies obtained through professional education. Teacher competency is comprehensive and is a unity that is mutually related and mutually supportive. The pedagogical competencies referred to in this study are, among others, the ability to understand students in depth and the implementation of educational learning. Understanding of students includes an understanding of the psychology of child development while educating learning includes the ability to design learning, implement learning, assess learning processes and outcomes, and make improvements in a sustainable manner. students who at least include: a). Understanding of insight or educational foundation. The teacher has a scientific education background so that he has academic and intellectual expertise.

Referring to the subject-based learning management system, the teacher should have a match between the scientific background and the subject being fostered. In addition, teachers have the knowledge and experience in organizing classroom learning. Authentically these two things can be proven by academic diplomas and teaching 
skills diplomas (teaching certificates) from government-accredited educational institutions. b). Understanding of students. The teacher has an understanding of the psychology of child development, so that he knows the right approach that is carried out on his students. The teacher can guide the child through difficult times in the age of the child. In addition, the teacher has knowledge and understanding of the child's personal background, so that he can identify the problems faced by the child and determine the right solutions and approaches. c). Development of curriculum / syllabus. The teacher has the ability to develop a national education curriculum that is tailored to the specific conditions of the school environment. d). Learning design. The teacher has a learning system plan that utilizes existing resources.

All learning activities from the beginning to the end can be planned strategically, including anticipating problems that might arise from the planned scenario. e). The implementation of learning that is educational and dialogical. The teacher creates learning situations for children who are creative, active and fun. Provide a broad space for children to be able to explore their potential and abilities so they can be trained and developed. f). Use of learning technology. In conducting learning, the teacher uses technology as a medium. Provide learning materials and administer using information technology. Getting children to interact using technology. g). Evaluation of learning outcomes. The teacher has the ability to evaluate the learning done including planning, children's response, children's learning outcomes, methods and approaches. To be able to evaluate, the teacher must be able to plan the right assessment, make measurements correctly, and make conclusions and solutions accurately. h). Development of students to actualize their various potentials. The teacher has the ability to guide children, creating a forum for children to recognize their potential and train to actualize their potential.

One effort that can be done to develop this capability is to carry out classroom action research. Class action research, based on planning and solutions to problems faced by children in learning. So that children's learning outcomes can increase and teacher planning targets can be achieved. In principle, all aspects of the pedagogical competence above can always be improved through the development of problem studies and alternative solutions.Pedagogic competence is a competency that contains academic scientific foundations regarding students' understanding; designing, implementing, evaluating learning, and developing students.

The important indicators of a teacher having pedagogical competence are as follows

a. Mastering the characteristics of students from physical, moral, social, cultural aspectsemotional, and intellectual.

b. Mastering learning theory and educational learning principles.

c. Mastering the curriculum related to the field of development being taught.

d. Skilled in carrying out an educational development field.

e. Utilizing information and communication technology for the benefit of organizing educational development activities.

f. Facilitate the development of potential students to actualize the various potentials they have.

g. Communicate effectively, empathically, and politely with students.

h. Skilled in evaluating and evaluating learning processes and results.

i. Use the results of assessment and evaluation for the benefit of learning.j. Reflective take action to improve the quality of learning

\subsection{Giving COmpensation}

A person works to give time and energy to the organization and as a counter-pretense, the organization provides compensation or compensation, whose forms can vary greatly. The system used by the organization in providing these benefits can affect work motivation and employee job satisfaction. Every organization applies a compensation system flexibly and freely in accordance with their respective conditions. Which system is deemed appropriate to provide compensation to workers in the hope that it can improve performance and foster job satisfaction.According to Justine T. Sirait in his book entitled "Understanding the Aspects of Managing Human Resources in Organizations" (2006: 180) that compensation is something that is received by employees, whether in the form of money or not money as a reward provided for employee efforts ( employee contributions) given to the organization.Kadarisman (2014: 1) suggests that compensation is what an employee / employee / worker receives in return for the work he is given.Ivancevich (1995) in Kadarisman (2014: 6), argues as follows: "Compensation is a function of Human Resource Management (HRM) related to each type of reward received by individuals in return for the implementation of organizational tasks. Employees exchange their energy to get financial and non-financial rewards.

According to Sudarmanto (2015: 192) the award (reward) has an understanding of the rewards / rewards given by the organization to its members, both in terms of financial material, non-financial material, as well as psychological or non-material. The manifestation of the award can be in the form of: basic salary / basic salary, variable salary, incentives / incentives, achievement fees (bonus), career opportunities / promotions, holidays, retirement."Compensation is anything that employees receive as a reward for their work". (Handoko, 2001: 155). Furthermore Rivai (2004: 357) argues that compensation is something that is received by employees as a substitute for their service contribution to the company. Whereas according to Hasibuan (1995: 133) compensation is all 
income in the form of money or goods directly or indirectly received by employees in return for services provided to the company.

According to Nitisemito (1988: 149) in Kambey (2013: 120) compensation is a remuneration provided by the company to its employees who can be valued with money and have a tendency to be given regularly. The same thing was stated by Nawawi (2003: 325-326) that "Giving compensation is as an award / reward for employees / members of the organization who have contributed through the implementation of work to achieve organizational goals". Especially for educational institutions for each education unit, giving compensation to teachers is often different and adjusted to the financial capabilities of the school. The difference in the provision of compensation by schools received by teachers, especially indirect compensation or permanent remuneration and incentives in schools is more focused on the achievement of teacher work performance.

Giving compensation is one of the implementation of HRM functions that deals with all types of individual awards in exchange for carrying out organizational tasks. This compensation is expenses and costs for the company, so that the company expects that the compensation paid will get a greater work performance benefit from the employee. Compensation issues are not only sensitive because they are driving people to work, but also affect morale and labor discipline. Therefore, any company or organization should be able to provide compensation that is balanced with the workload borne by the workforce. Thus, the purpose of fostering labor is to create a workforce that is efficient and effective can be realized.The purpose of giving compensation to employees according to Handoko (2001: 157) there are six objectives, are: (1) obtaining qualifiet personnel, (2) maintaining existing employees, (3) guaranteeing justice, (4) respecting desired behavior, (5 ) controlling costs, and (6) fulfilling legal regulations.

Giving compensation is an important factor that influences how and why someone chooses to work for an organization. Compensors are more competitive and selective in applying certain types of compensation. (Winarni and Sugiyarso, 2006: 11). According to Mathis and Jakson (2006: 420), compensation consists of: (1) Direct compensation, in the form of basic salary such as wages, salaries, and in the form of irregular income such as bonuses, incentives, options, shares. (2) indirect compensation, in the form of benefits such as health insurance, leave, and pension.

Hasibuan (1995: 133) distinguishes compensation in two groups, namely direct compensation (direct compensation) in the form of salaries, wages, incentive wages and indirect compensation (indirect compensation, or employee welfare). Whereas Nawawi (1997: 316-317) in Kambey (2013: 127) divides compensation in three types, namely; direct compensation in the form of rewards called salaries or wages, which are paid regularly based on a fixed grace period and indirect compensation in the form of other benefits for workers outside of a fixed salary or wage, as well as incentives in the form of rewards to motivate workers to have high productivity, are nonpermanent or at any time, as part of profits, mainly given to workers who work well, and excel.

the model theoritical frame can be seen in the picture below

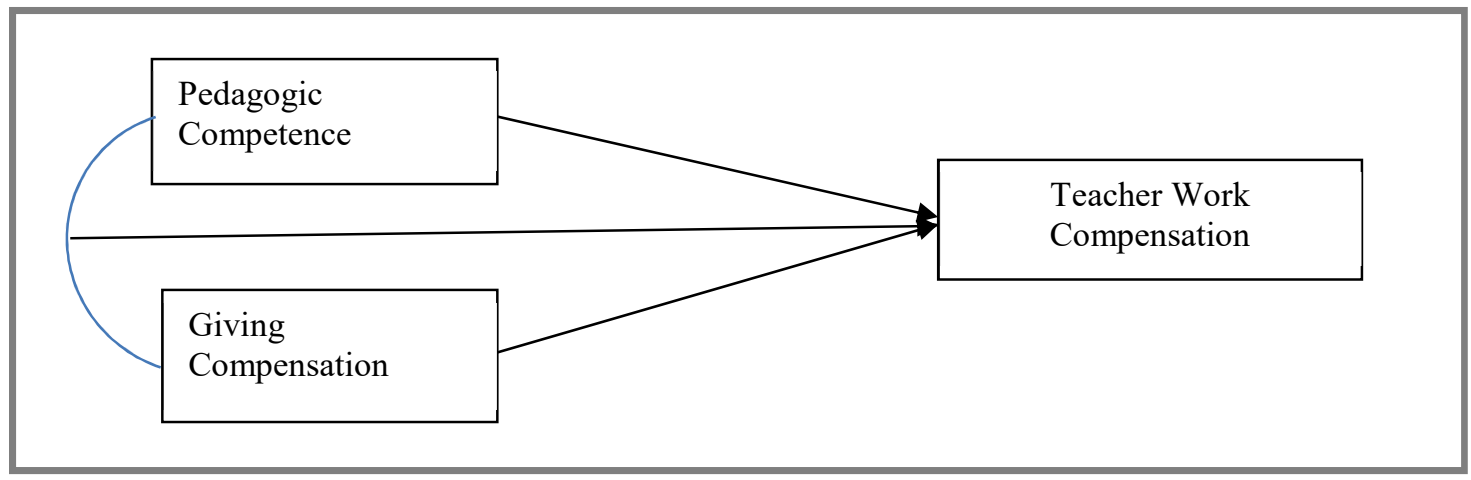

Figure 1. Theoritical Framework Model

\section{Research Method}

Object that becomes the variable in this study is Pedagogic competence, Giving compensation and working motivation of teachers at Manado State Vocational School. While the subjects of the analysis are teachers at the Manado City Public Vocational School. The research location is State Vocational Schools in Manado City. This research was conducted from October 2018 to April 2019.

The population in this study is the overall characteristics of the study regarding pedagogic competence of teachers, the provision of teacher compensation and teacher work motivation with the population unit are all teachers at the Manado City Public Vocational School with a total of 504 people spread across 9 (nine) Public Vocational Schools in Manado City and recorded in the data teachers of Manado City State Vocational School Academic Year 2018/2019Determination of the sample in this study will use an error rate of $10 \%$, with a 
confidence level of $95 \%$ using the formula from Taro Yamane. Using this formula, a sample of 84 teachers was obtained. Can be seen on table 1 below

\begin{tabular}{|c|l|c|c|}
\hline No. & \multicolumn{1}{|c|}{ School } & Number of sample & Total \\
\hline 1 & SMK Negeri 1 Manado & $\frac{84}{504}=98=16,3$ & 16 \\
\hline 2 & SMK Negeri 2 Manado & $\frac{84}{504}=106=17,6$ & 18 \\
\hline 3 & SMK Negeri 3 Manado & $\frac{84}{504}=95=15,8$ & 16 \\
\hline 4 & SMK Negeri 4 Manado & $\frac{84}{504}=20=3,3$ & 3 \\
\hline 5 & SMK Negeri 5 Manado & $\frac{84}{504}=73=12,1$ & 12 \\
\hline 6 & SMK Negeri 6 Manado & $\frac{84}{504}=63=10,5$ & 11 \\
\hline 7 & SMK Negeri 7 Manado & $\frac{84}{504}=26=4,33$ & 4 \\
\hline 8 & SMK Negeri 8 Manado & $\frac{84}{504}=13=2,16$ & 2 \\
\hline 9 & SMK Negeri 9 Manado & $\frac{84}{504}=10=1,66$ & 2 \\
\hline & total & $\mathbf{5 0 4}$ & $\mathbf{8 4}$ \\
\hline
\end{tabular}

To test the validity of the questionnaire in this study carried out with two forms of testing, namely (a) test the validity of content (conten validity), to test the extent to which through verification of three expert lecturers, (b) test the validity of statement items, testing carried out by calculating the correlation between each statement with a total score, using product moment correlation techniques. The calculated $r$ value is matched with $r$ product moment table at a significant level of 5\%. If $r$ count is greater than $r$ table $5 \%$, then the item is valid. Tests are carried out by applying the computer testing program Statistical Product and Service Solution (SPSS) 21 Pearson correlation. The $\mathrm{r}$ prices for each item statement are then compared with the critical number of the r-value correlation table. How to see the correlation table withsee line $\mathrm{N}$ on the 2-sided test (For $\mathrm{N}=30$, obtained $\mathrm{r}$ table $=0.361$ ) Appendix 8, If the price correlation score for each item statement with a total score produces $r$ count $<$ from $r$ table, the item is aborted (invalid).

Reliability test is used to determine the consistency of the measuring instrument, whether the measuring device used is reliable and remains consistent if the measurement is repeated. There are several reliability testing methods including retesting methods, Flanagan formula, Cronbach's Alpha, KR-20, KR-21, and Anova Hoyt method. The method often used in research is the Cronbach's Alpha method. The method that is very suitable for use in dichotomous scores ( 0 and 1$)$ and will produce an equivalent calculation using the KR-20 and Anova Hoyt methods. Reliability means "can be trusted" That is, the instrument can provide the right results. The instrument measuring instrument is categorized as reliable if it shows the measurement results constants and has the measurement results so it is proven that the measuring instrument can really be justified. Testing the validity and reliability of the questionnaire can use SPSS.Test decisions are if $r$ alpha is positive or negative and $r$ alpha $>r$ table, then the variable is reliable. Reliability is expressed by the reliability coefficient whose numbers differ in the range 0 to 1 . The closer the number 1 and 0.632 the higher the reliability. Conversely, if it approaches 0 , the reliability is getting lower (Sugiyono, 2007).

Based on the results of the test, it can be seen that the questionnaire reliability coefficient pedagogic competence variable $(\mathrm{X} 1) \mathrm{r} 1=0.971$, teacher compensation $\mathrm{r} 1=0.969$, and the Aplha-Cronbach reliability coefficient $(\mathrm{r}=0.981)$. The data analysis technique in this study uses simple correlation analysis and multiple regression analysis with the help of SPSS 21 . The stages of the analysis include (1) descriptive analysis, (2) test requirements analysis, (3) hypothesis testing

\section{Result and Discussion}

\subsection{Deskriptif Data Motivation of Teacher's Work.}

Based on the main data of the study, it can be seen that from 84 research respondents, the highest score was 185 and the lowest score was 87 of the highest ideal score of 195 and the lowest ideal score was 39 . With a descriptive statistical count (Appendix VII, p. 112) it is known that the average price of the teacher's work motivation score is 137.01 the standard deviation is 22.909 and the median is 138.5. To determine the number of intervals the class is calculated using the Sturges formula as follows: $K=1+3.3 \log n$, where $n=84 K=1+3.3 \log 84=7.35$ rounded 8From the calculation results, the number of intervals 8 with the length of class 13 . 
To see the level of work motivation of the State Vocational School teachers in the city of Manado whether it is in the low, medium, high, or very high category, then this variable can be simplified from 8 interval classes to 4 categories.

\subsection{Deskriptif Data Giving Compensation}

Based on the main data of the study, it can be seen that from 84 research respondents, the highest score was 122 and the lowest score was 67 from the highest ideal score of 135 and the lowest ideal score was 27. With the calculation of descriptive statistics it is known that the average price of the compensation score is 94.15 , the standard deviation is 13.087 and the median is 94 To determine the number of intervals the class is calculated using the Sturges formula as follows: $\mathrm{K}=\mathrm{I}+3.3 \log \mathrm{n}$, where $\mathrm{n}=84 \mathrm{~K}=1+3.3 \log 84=7.35$ rounded 8From the calculation results, the number of intervals 8 with class 7 is obtained.

To see the behavior effectiveness of compensation that is perceived by the State Vocational School teachers in the city of Manado whether it is in the low, medium, high, or very high category, then this variable can be simplified from 8 interval classes to 4 categories

\subsection{Hypothesis Testing Results}

The first result testing hypothesis.

Based on the results of testing using the $Z$ test it turns out that the level of teacher perceptions of giving compensation from 84 teacher respondents was sufficient at $a=0.05$. Zhit Value $(=2.81)>Z(0.05)(=1.65)$; then Ho is rejected. This means that the level of teacher perceptions of pedagogical abilities is sufficient (more than $70 \%$ ). Hypothesis 1 which states the level of pedagogical skills of the State Vocational School teachers in Manado city is quite feasible. The results of the study indicate that the research hypothesis was tested. In other words, the level of teacher's pedagogic ability is quite good. The results of this research can be interpreted that the teachers of State Vocational Schools in the city of Manado have high willingness and responsibility as professional teachers. The second result testing hypothesis:

Level of perception of compensationFor the variable giving compensation based on the results of testing, it was obtained that the value of Zhit was significant at $\alpha=0.05$. The value of Zhit obtained is 3.30. Because the value of Zhit $(=3.30)>Z(0.05)(=1.65)$; then Ho is rejected. This means that the level of compensation is sufficient (more than 70\%). Hypothesis 2, which states the level of perceptions of providing compensation for teachers of public vocational schools in the city of Manado, is quite good. The results of the study indicate that the research hypothesis was tested. In other words, the level of perception of teacher compensation at State Vocational Schools in the city of Manado from the 84 respondents studied was good enough.

The third result testing hypothesis:

The level of motivation of the work of the teacher. As for the dependent variable of teacher work motivation, the results of hypothesis testing show Zhit $(=2.81)>Z(0.05)=1.65)$; thenHo rejected. This means that the teacher's work motivation level is quite good (more than 70\%). Hypothesis 3 which states that the work motivation of the State Vocational School teachers in the city of Manado is adequate. The results of the study indicate that the research hypothesis was tested. In other words, the work motivation of teachers in State Vocational Schools in Manado city from the 84 respondents studied was adequate. The results of this study can be interpreted that the teachers of State Vocational Schools in the city of Manado have had a high ability to motivate according to their duties and responsibilities as professional teachers.

The fourth result testing hypothesis:

Teacher's pedagogic ability with teacher motivation. Based on the results of the simple regression analysis above, it can be stated that the teacher's pedagogical ability contributes and is significant at the $95 \%$ level towards the teacher's work motivation. This means that the higher the pedagogical ability of the teacher, the higher the motivation of the work of the teacher. In other words, the teacher's work motivation depends on the teacher's pedagogical abilities.

The fifth result testing hypothesis: Based on the resultsthe simple regression analysis above can be stated that the provision of compensation contributes and is significant at the $95 \%$ level to the teacher's work motivation. This means that the higher the compensation, the higher the motivation of the teacher's work. In other words, the teacher's work motivation depends on giving compensation.

Hypothesis 4 which states that pedagogic ability has a significant contribution to the work motivation of teachers of public vocational schools in the city of Manado. The results of the study indicate that this hypothesis has been tested. In other words, the pedagogic ability of the teacher has a significant contribution to teacher work motivation at the level of testing determined $\mathrm{a}=0.05$.

The fifth result testing hypothesis:

Giving compensation by motivating teacher work. To test this hypothesis, it is necessary to test the regression direction coefficient $\mathrm{Y}$ on X2. From the results of simple regression analysis the regression equation is obtained: $\mathrm{Y}=28,497+1,153 \mathrm{X} 2$. R Square $(r)=0.433$. Price statistics Fh, w , $g=58,153$. So that the results of the study 
obtained Fh, W , g $(=58,153)>\mathrm{F}(\mathrm{o}, 95)(1,76)=(4,000)$, thus the Hypothesis Ho is accepted. Based on the resultsthe simple regression analysis above can be stated that the provision of compensation contributes and is significant at the $95 \%$ level to the teacher's work motivation. This means that the higher the compensation, the higher the motivation of the teacher's work. In other words, the teacher's work motivation depends on giving compensation. Hypothesis 5 which states that compensation has a significant contribution to the work motivation of teachers in the State Vocational School in the city of Manado. The results of this study indicate that the provision of compensation provides a significant contribution to the work motivation of teachers of Vocational Schools in the city of Manado.

The sixth result testing hypothesis:

The teacher's pedagogical ability, giving compensation together contributes and significantly influences the teacher's work motivation. To test this hypothesis what needs to be done is testing regression direction coefficient $\mathrm{Y}$ for $\mathrm{X} 1$ and $\mathrm{X} 2$. From the results of double regression analysis obtained by the regression equation: $\mathrm{Y}=-10,139$ $+0,556 X,+0,927 X 2$. R Square $(r)=0.580$. Price statistic $F$ count $=51,776$. So that the results of the study obtained Fcount $(=51,776)>\mathrm{F}(0.95)(2.75)(=3,150)$, thus the Hypothesis Ho is accepted. Based on the results of the multiple regression analysis above, it can be stated that pedagogic competence, compensation, together contribute and are significant at the $95 \%$ level of teacher work motivation. This means that the higher the pedagogical competence, the provision of compensation contributes to the higher motivation of the teacher's work. In other words, the teacher's work motivation depends on pedagogic competence, compensation.

Hypothesis 5 which states that compensation has a significant contribution to the work motivation of teachers in the State Vocational School in the city of Manado. The results of this study indicate that the provision of compensation provides a significant contribution to the work motivation of teachers of Vocational Schools in the city of Manado.

\section{Conclussion}

Based onthe study, conclusions can be drawn as follows:1. In general, the level of feasibility of pedagogical skills of state vocational school teachers in the city of Manado is quite high. This means that teachers in general have fully understood the duties, work and obligations of the teacher so that they can carry out professionally.2. In general, the provision of compensation that is perceived by state vocational school teachers in the city of Manado is already quite high. This means that compensation has been carried out fairly. The level of teacher perceptions of the provision of compensation for State Vocational Schools in the city of Manado is quite feasible.3. In general the work motivation of the State Vocational School teachers in the city of Manado is quite high. This means that the work motivation of teachers at Manado City Vocational School is quite good.4. The pedagogical ability of the teacher has a significant contribution to the motivation of work of the State Vocational School teachers in the city of Manado. This means that the higher the pedagogical ability of the teacher will also contribute high to the motivation of the teacher's work. This means that the work motivation of the teacher depends on pedagogic abilities.5. The provision of compensation has a significant contribution to the motivation of work of the State Vocational School teachers in the city of Manado. This means that the provision of compensation contributes significantly to the work motivation of the teacher.6. Teacher's pedagogical ability and the provision of compensation together have a significant contribution to the work motivation of teachers of Vocational Schools in the city of Manado. This means that the teacher's pedagogic ability and compensation, together provide meaningful contributions to the motivation of teacher work

\section{References}

Arikunto S, 2010. Prosedur Penelitian Suatu Pendekatan Praktek. Jakarta. Rineka Cipta.

Aritonang KT, 2012. Kompensasi Kerja, Disiplin Kerja Guru Dan Kinerja Guru

Dessler G, 2012. Manajemen Sumber Daya Manusia (terjemahan Eli Tanya). Jilid 1. Jakarta. Indeks Kelompok Gramedia.

Handoko. H. T. 2014. Manajemen Personalia \& Sumber Daya Manusia. Yogyakarta. BPFE

Hasanah A, 2013. Pengaruh Perilaku Kepemimpinan Kepala Sekolah Terhadap Kinerja Guru Di SMK Kota Bandung.

Hasibuan MSP, 2012. Manajemen Sumber Daya Manusia. Jakarta. Toko Gunung Agung.

Kewo, C. L., \& Afiah, N. N. (2017, July). Pengaruh Penganggaran Partisipatig, Kejelasan Sasaran Anggaran Dan Implementasi Pengendalian Intern Terhadap Kinerja Manajerial Instansi Pemerintah Daerah Seta Implikasinya pada Akuntabilitas Keuangan. Seminar Nasional Akuntansi dan Bisnis (SNAB), Fakultas Ekonomi Universitas Widyatama.

Kambey D.C,2013. Manajemen Sumber Daya Manusia. Manado. Yayasan Triganesha Nusantara . Manado

Kim Jae, O and Kohort Frank, J. 1975. Multiple Regretion Analysis:Program Regression in Statiscal Package for The Social Science. New York Mc-Graw-Hill book Company.

Mangkunegara A P, 2015. Evaluasi Kinerja SDM. Bandung. Refika Aditama. 
Mathis RL, Jackson JH., 2013. Manajemen Sumber Daya Manusia. (terjemahan Sadeli, J dan Bayu Prawira Hie). Buku 1. Jakarta. Salemba Empat.

Nawawi, 2013. Kepemimpinan Mengefektifkan Organisasi. GUMP. Jakarta.

Pasandaran. Sj dkk, 2009.Profesionalisme Guru ( Materi Pendidikan dan Latihan Profesi Guru Rayon 27 Universitas Negeri Manado). Manado.Departemen Pendidikan nasional Universitas negeri Manado.

Riduwan, 2010. Metode \& Teknik Menyusun Tesis. Bandung. Alfabeta.

Rivai V, 2014. Manajemen Sumber Daya Manusia Untuk Perusahaan dari Teori Ke Praktik. Jakarta. RajaGrafindo Persada.

Robbins SP, 2003. Perilaku Organisasi (ed. Bahasa Indonesia). Buku 1 \& 2. Jakarta. Indeks Kelompok Gramedia Saruan S, 2009. Tesis "Pemberian Kompensasi, Motivasi Kerja dan Prestasi Kerja Guru SMP Negeri di Kota Manado".

Sastrohadiwiryo S, 2010. Manajemen Tenaga Kerja (Pendekatan Administrasi dan Tenaga Kerja). Jakarta. Bumi Aksara

Sedarmayanti, 2010. Sumber daya manusia Dan Produktivitas Kerja. Bandung. Mandar Maju.

Siagian SP, 2004. Teori Motivasi Dan Aplikasinya. Jakarta. Rineka Cipta.

SMP Kristen BPS Penabur Jakarta

Soedjadi, 1995. O \& M (Organization and Methods) Penunjang Berhasilnya Proses Manajemen. Jakarta. Gunung Agung.

Stoner JAF, Freemand RE. dan Gilbert Jr DR. (Tanpa tahun). Manajemen.

Sudjana, N. 1996. Statistika.Bandung: Tarsito.

Sugema TB, Soetrisno, 2000. Motivasi dalam Organisasi. Bahan Diklat Staf dan Pimpinan Administrasi Tingkat Pertama. Lembaga Administrasi Negara.

Sugiyono, 2017. Penelitian Pendidikan Pendekatan kuantiyatif, Kualitatif dan R \& D. Alfabeta : Bandung.

Sumarsono S, 2014. Metode Riset Sumber Daya Manusia. Yogyakarta. Graha Ilmu.

Supomo B, Indriantoro N, 2012. Metodologi Penelitian Bisnis untuk Akuntansi \& Manajemen. Edisi Pertama. Yogyakarta. BPFE-Yogyakarta.

Surapranata,S.2014. Analisis, Validitas, Reliabilitas dan Interpretasi Hasil Tes Implementasi Kurikulum 2004. PT. Remaja Rosdakarya : Bandung

Sutermeister, Robert A. 1976.People and Productivity, New York. MCGraw-Hill Book Company

Terry GR, 1993. Prinsip - Prinsip Manajemen (terjemahan J. Smith D.F.M). Jakata. Bumi Aksara.

Thoha M,1983. Perilaku Organisasi, Konsep Dasar dan Aplikasinya. Jakarta. Grafindo PersadaJakarta

Tunggal AW, 2010. Kamus manajemen Sumber Daya Manusia \& Perilaku Organisasi. Jakarta. Rinrka Cipta.

Undang-Undang Republik Indonesia No 14 Tahun 2005. Tentang Guru dan Dosen. Departemen Pendidikan Naional Republik Inddonesia. Jakarta.

Undang-Undang Republik Indonesia Nomor 20 Tahun 2003.Tentang Sistim Pendidikan Nasional. Diknas Jakarta. Usman H. 2012. Manajemen, Teori, Praktik, dan Riset Pendidikan. Jakarta. Bumi Aksara.

Walpole R.E.1990. Pengantar Statistika.Gramedia. Jakarta.

Winardi, 2000. Kepemimpinan Dalam Manajemen. Jakarta. Rineka Cipta.

Winarni F. \& Sugiyarso G. 2006. Administrasi Gaji dan Upah. Pustaka Widyatama : Yogyakarta.

Wuviani V, 2004. Faktor-Faktor Yang Mempengaruhi Kinerja Guru (Studi Tentang Pengaruh Kualifikasi, Motivasi Kerja Guru dan Kepemimpinan Kepala Sekolah Terhadap Kinerja Guru Di Kota Bandung) 